\title{
Alteration of Bone Turnover Markers in Canonical Wingless Pathway in Patients With Ankylosing Spondylitis
}

\author{
Jinxian HUANG, ${ }^{1}$ Guoxiang SONG, ${ }^{2}$ Zhihua YIN, ${ }^{3}$ Zhongchao FU, ${ }^{3}$ Zhizhong $\mathrm{YE}^{3}$ \\ ${ }^{1}$ Department of Rheumatology, The University of Hong Kong-Shenzhen Hospital, Shenzhen, China \\ ${ }^{2}$ Department of Ophthalmology, The Third People's Hospital of Shenzhen, Shenzhen, China \\ ${ }^{3}$ Department of Rheumatology, The Fourth People's Hospital of Shenzhen, Shenzhen, China
}

\begin{abstract}
Objectives: This study aims to determine the levels of bone turnover markers in canonical wingless pathway in patients with ankylosing spondylitis (AS) and the correlation with disease activity indexes.

Patients and methods: We recruited a total of 43 AS patients (34 males, 8 females; mean age $36.8 \pm 9.3$ years; range 22 to 62 years) and age- and sex-matched 42 healthy controls ( 32 males, 10 females; mean age $36.1 \pm 9.7$; range 24 to 59 years). Serum levels of components of canonical wingless pathway including Dickkopf-1, glycogen synthase kinase-3 $\beta, \beta$-catenin, alkaline phosphatase, and osteocalcin were detected using enzymelinked immunosorbent assay method. All patients were assessed in terms of erythrocyte sedimentation rate, C-reactive protein, Bath Ankylosing Spondylitis Disease Activity Index, Bath Ankylosing Spondylitis Functional Index, Ankylosing Spondylitis Disease Activity Score, and the modified Stoke's Ankylosing Spondylitis Spine Score. Pearson's correlation test was used to analyze the correlation between serum bone turnover markers and clinical assessment indexes.

Results: No significant difference was observed between AS patients and healthy controls for the levels of glycogen synthase kinase- $3 \beta$, $\beta$-catenin, alkaline phosphatase, and osteocalcin, respectively ( $p>0.05)$. The level of Dickkopf- 1 was significantly higher in AS patients (1914.5 $\pm 407.8 \mathrm{pg} / \mathrm{mL}$ ) than in healthy controls $(1729.1 \pm 352.9 \mathrm{pg} / \mathrm{mL})(\mathrm{p}<0.05)$. There was no correlation between high Dickkopf- 1 level and any of the clinical parameters contributing to inflammation or bone formation. However, the correlation between osteocalcin and disease duration was significant in AS patients $(r=0.323, p=0.034)$.

Conclusion: Alteration of bone turnover markers in canonical wingless pathway was observed in AS. This might partially explain the complicated mechanism of bone formation in the disease.

Keywords: Ankylosing spondylitis; bone turnover; canonical wingless pathway.
\end{abstract}

Ankylosing spondylitis (AS) is a chronic inflammatory disorder mainly affecting the spine and sacroiliac joints, characterized by new bone formation that progressively leads to ankylosis and functional disability. Syndesmophytosis are pathological hallmarks of AS, which results from new bone formation induced by chronic inflammation and further structural damage.

The mechanisms that lead to bony fusion in AS are yet to be fully defined. Aberrant regulation of the wingless (Wnt) pathway has been suggested as a key element in the pathogenesis of AS. ${ }^{1}$ There has been evidence for the involvement of this pathway in AS bone formation in vitro studies. As Wnt signaling inhibitors, the expression of Dickkopf (DKK)-1 and sclerostin were reduced in the spine of proteoglycan-induced spondylitis mice $^{2}$ and blockade of DKK-1 induces fusion of sacroiliac joints in tumor necrosis factor (TNF) transgenic mice, ${ }^{3}$ implicating the Wnt pathway as a likely mediator of the mechanism by which inflammation induces bony ankylosis in spondyloarthritis. 
Dickkopf-1 is a bone-specific inhibitor of the canonical Wnt pathway; if DKK-1 is not able to bind to low-density lipoprotein receptor-related protein $5 / 6,{ }^{4}$ Wnt proteins might interact with the receptors, resulting in dephosphorylation

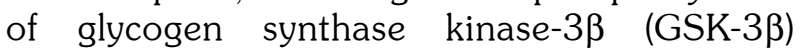
and activation of $\beta$-catenin. Beta-catenin is subsequently translocated into the nucleus to form a transcriptionally active $\beta$-catenin $\mathrm{T}$-cell factor/lymphoid enhancer factor deoxyribonucleic acid-binding complex that regulates the Wnt target gene. Canonical Wnt signaling promotes osteogenesis by directly stimulating Runx 2 gene expression. Runx 2 activates osteocalcin (OC), which is an osteoblast-specific gene expressed by differentiated osteoblasts. ${ }^{5,6}$

In theory, the activation of Wnt pathway would be facilitated by decreased expression of DKK-1, while the serum expression of DKK-1 in AS has been controversial. ${ }^{7-18}$ To the best of our knowledge, other components of Wnt pathway have not yet been studied.

We hypothesize that alteration of the components of canonical Wnt signaling, such as down regulation of negative regulators, might contribute to the activation of the pathway and effector gene expression and finally lead to the bone formation in AS. Therefore, in this study, we aimed to determine the levels of bone turnover markers in canonical Wnt pathway in patients with AS and the correlation with disease activity indexes.

\section{PATIENTS AND METHODS}

We consecutively enrolled 43 AS patients (34 males, 8 females; mean age $36.8 \pm 9.3$ years; range 22 to 62 years) and age and sex similar 42 healthy controls (32 males, 10 females; mean

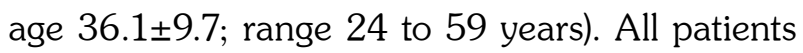
were diagnosed with AS according to the modified New York criteria. ${ }^{19}$ Bath Ankylosing Spondylitis Disease Activity Index, Bath Ankylosing Spondylitis Functional Index, and Ankylosing Spondylitis Disease Activity Scores ${ }^{20,21}$ were assessed for all patients. All patients underwent an X-ray of the cervical and lumbar spine to calculate the modified Stoke's Ankylosing Spondylitis Spine Score. ${ }^{22}$ The study was approved by the local bioethics committee and all participants signed informed consents. The study was conducted in accordance with the principles of the Declaration of Helsinki.

Samples were centrifuged immediately and serum was separated and stored at $-80{ }^{\circ} \mathrm{C}$. Markers involving in the Wnt signaling pathway including DKK-1, GSK-3 $\beta$, $\beta$-catenin, alkaline phosphatase (ALP) and OC were measured by using commercially available enzyme-linked immunosorbent assay tests (DKK-1, GSK-3 $\beta$ and $\beta$-catenin: EIAab Science Co. Ltd., Wuhan, China; OC: Immunodiagnostic Systems Ltd.). Erythrocyte sedimentation rate and C-reactive protein as well as human leukocyte antigen-B27 were detected for all AS patients.

\section{Statistical analysis}

Data for continuous variables are presented as mean \pm standard deviation. The Kolmogorov Smirnov test was used to test the normality of distribution of continuous variables. Independent t-test was used to test for the differences in continuous variables between two groups. Pearson's coefficient of correlation was used for bivariate correlations between continuous variables. P value $<0.05$ was considered statistically significant in all the above tests. Statistical analysis was performed using SPSS for Windows version 13.0 software (SPSS Inc., Chicago, IL, USA).

\begin{tabular}{|c|c|c|c|}
\hline & AS patients $(n=43)$ & Healthy controls $(n=42)$ & \\
\hline & Mean \pm SD & Mean \pm SD & $p$ \\
\hline Dickkopf-1 (pg/mL) & $1914.5 \pm 407.8$ & $1729.1 \pm 352.9$ & 0.028 \\
\hline Glycogen synthase kinase $-3 \beta(\mathrm{ng} / \mathrm{mL})$ & $0.7 \pm 0.6$ & $0.6 \pm 0.4$ & 0.376 \\
\hline$\beta$-catenin (ng/mL) & $2.3 \pm 1.0$ & $2.5 \pm 0.8$ & 0.223 \\
\hline Alkaline phosphatase (U/L) & $73.6 \pm 19.6$ & $72.8 \pm 14.5$ & 0.828 \\
\hline Osteocalcin (ng/mL) & $11.0 \pm 8.3$ & $11.5 \pm 8.2$ & 0.763 \\
\hline
\end{tabular}




\begin{tabular}{|c|c|c|c|c|c|}
\hline & DKK-1 & GSK-3 $\beta$ & $\beta$-catenin & ALP & $\mathrm{OC}$ \\
\hline \multicolumn{6}{|c|}{ Dickkopf-1 (pg/mL) } \\
\hline$r$ & & 0.300 & 0.266 & 0.069 & 0.150 \\
\hline $\mathrm{p}$ & & 0.050 & 0.085 & 0.662 & 0.337 \\
\hline \multicolumn{6}{|c|}{ Glycogen synthase kinase $-3 \beta(\mathrm{ng} / \mathrm{mL})$} \\
\hline $\mathrm{r}$ & 0.300 & & 0.164 & -0.223 & 0.001 \\
\hline $\mathrm{p}$ & 0.050 & & 0.293 & 0.150 & 0.993 \\
\hline \multicolumn{6}{|c|}{$\beta$-catenin (ng/mL) } \\
\hline $\mathrm{r}$ & 0.266 & 0.164 & & 0.057 & -0.279 \\
\hline $\mathrm{p}$ & 0.085 & 0.293 & & 0.717 & 0.070 \\
\hline \multicolumn{6}{|c|}{ Alkaline phosphatase (U/L) } \\
\hline $\mathrm{r}$ & -0.069 & -0.223 & 0.057 & & -0.070 \\
\hline $\mathrm{p}$ & 0.662 & 0.150 & 0.717 & & 0.658 \\
\hline \multicolumn{6}{|c|}{ Osteocalcin (ng/mL) } \\
\hline $\mathrm{r}$ & 0.150 & 0.001 & -0.279 & -0.070 & \\
\hline $\mathrm{p}$ & 0.337 & 0.993 & 0.070 & 0.658 & \\
\hline
\end{tabular}

\section{RESULTS}

Human leukocyte antigen-B27 positivity was 88.37\%. Among the 43 AS patients, six had peripheral arthritis involvement including four males and two females. Mean disease duration was $8.9 \pm 7.6$ years. Erythrocyte sedimentation rate and C-reactive protein were $22.3 \pm 20.6 \mathrm{~mm} / \mathrm{h}$ and $12.8 \pm 13.6 \mathrm{mg} / \mathrm{L}$, respectively. Mean Bath Ankylosing Spondylitis Disease Activity Index, Bath Ankylosing Spondylitis Functional Index and Ankylosing Spondylitis Disease Activity Score were $4.0 \pm 1.9,43.0 \pm 21.5$ and $2.0 \pm 1.0$, respectively. Mean modified Stoke's Ankylosing

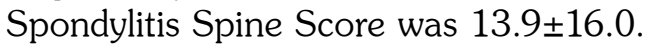

The levels of DKK-1 was significantly higher in AS patients $(1914.5 \pm 407.8 \mathrm{pg} / \mathrm{mL})$ than in healthy controls $(1729.1 \pm 352.9 \mathrm{pg} / \mathrm{mL})(\mathrm{p}<0.05)$. No significant difference was observed between AS patients and healthy controls for the levels of GSK-3 $\beta, \beta$-catenin, ALP and OC, respectively ( $\mathrm{p}>0.05)$ (Table 1).

Among the bone turnover markers in canonical Wnt pathway, no correlation was observed between the two markers in AS patients. Nonetheless, the correlation between several markers (DKK-1 and GSK-3 $\beta$ : $p=0.050$; DKK-1 and $\beta$-catenin: $p=0.085 ; \beta$-catenin and $\mathrm{OC}$ : $\mathrm{p}=0.070$ ) almost reached significance (Table 2).

Table 3. Correlations between bone turnover markers and clinical parameters in ankylosing spondylitis patients

\begin{tabular}{|c|c|c|c|c|c|c|c|}
\hline & $\begin{array}{c}\text { ESR } \\
(\mathrm{mm} / \mathrm{h})\end{array}$ & $\begin{array}{c}\mathrm{CRP} \\
(\mathrm{mg} / \mathrm{L})\end{array}$ & $\begin{array}{c}\text { Disease course } \\
\text { (years) }\end{array}$ & BASDAI & BASFI & ASDAS & mSASSS \\
\hline \multicolumn{8}{|c|}{ Dickkopf-1 (pg/mL) } \\
\hline r & -0.087 & -0.043 & 0.076 & -0.190 & -0.147 & -0.108 & -0.233 \\
\hline $\mathrm{p}$ & 0.581 & 0.786 & 0.629 & 0.223 & 0.347 & 0.489 & 0.132 \\
\hline \multicolumn{8}{|c|}{ Glycogen synthase kinase- $3 \beta$ (ng/mL) } \\
\hline r & -0.139 & -0.136 & -0.176 & -0.115 & -0.067 & -0.049 & -0.001 \\
\hline $\mathrm{p}$ & 0.374 & 0.384 & 0.258 & 0.463 & 0.672 & 0.757 & 0.992 \\
\hline \multicolumn{8}{|c|}{$\beta$-catenin (ng/mL) } \\
\hline $\mathrm{r}$ & 0.044 & 0.023 & -0.057 & 0.036 & 0.087 & 0.075 & 0.027 \\
\hline $\mathrm{p}$ & 0.782 & 0.885 & 0.719 & 0.818 & 0.577 & 0.633 & 0.864 \\
\hline \multicolumn{8}{|c|}{ Alkaline phosphatase (U/L) } \\
\hline r & 0.081 & 0.244 & -0.162 & 0.295 & 0.277 & 0.288 & 0.151 \\
\hline $\mathrm{p}$ & 0.606 & 0.114 & 0.299 & 0.055 & 0.072 & 0.062 & 0.335 \\
\hline \multicolumn{8}{|c|}{ Osteocalcin (ng/mL) } \\
\hline r & 0.008 & 0.037 & 0.323 & 0.015 & 0.019 & 0.085 & -0.256 \\
\hline $\mathrm{p}$ & 0.959 & 0.816 & 0.034 & 0.922 & 0.903 & 0.589 & 0.098 \\
\hline
\end{tabular}


Likewise, there was no correlation between high DKK-1 level and any of the clinical parameters contributing to inflammation or bone formation. However, the correlation between $\mathrm{OC}$ and disease duration was significant in AS patients $(r=0.323, p=0.034)$. We also noticed that the correlation between ALP and Bath Ankylosing Spondylitis Disease Activity Index, Bath Ankylosing Spondylitis Functional Index, and Ankylosing Spondylitis Disease Activity Score nearly achieved significance with $p$ values of $0.055,0.072,0.062$, respectively (Table 3 ).

\section{DISCUSSION}

Our study demonstrated the expression of bone turnover markers in the downstream of canonical Wnt pathway. As for the widely investigated negative regulator of canonical Wnt pathway, DKK-1 upregulation was replicated in our study. Some previous studies supported the downregulation of DKK-1 and the probable activation of Wnt signaling, while others showed no significant difference between AS patients and controls, or even higher expression of DKK-1 in AS patients than in controls ${ }^{7,18}$ (supplemental data 1). There are at least three explanations for this contradictory situation. First, the dysfunction of DKK-1 was more in cellular level, instead of that in serum. DKK-1 binding to low-density lipoprotein receptor-related protein- 6 has been reported to be reduced in AS. ${ }^{23}$ And the functional capacity of DKK-1 from the sera of patients with AS to directly antagonize Wnt signaling was proved

Supplemental data 1. Dickkopf-1 expression in ankylosing spondylitis patients in published studies

\begin{tabular}{|c|c|c|c|c|c|c|}
\hline Author & $\begin{array}{l}\text { Number } \\
\text { (AS/HC) }\end{array}$ & $\begin{array}{l}\text { DKK level in AS } \\
(\mathrm{pg} / \mathrm{mL})\end{array}$ & $\begin{array}{l}\text { DKK-1 level in HC } \\
(\mathrm{pg} / \mathrm{mL})\end{array}$ & $p$ & Correlation & $\begin{array}{l}\text { Response to } \\
\text { TNF- } \beta \text { inhibitor }\end{array}$ \\
\hline Kwon et al. ${ }^{[7]}$ & $56 / 40$ & $12321 \pm 6136$ & $20811 \pm 5671$ & $<0.0001$ & NA & Not changed \\
\hline Ustun et al. ${ }^{[8]}$ & $44 / 41$ & $314.96 \pm 196.73$ & $613.34 \pm 861.86$ & 0.062 & $\begin{array}{c}\text { No association with } \\
\text { sclerostin, BASDAI, } \\
\text { BASRI, ESR, and } \\
\text { CRP }\end{array}$ & $\begin{array}{l}\text { Similar in } \\
\text { patients } \\
\text { with or without } \\
\text { treatment }\end{array}$ \\
\hline Yucong et al. ${ }^{[9]}$ & $84 / 79$ & $\begin{array}{c}\text { Total: } 3627 \\
\text { (1042-6179) } \\
\text { Functional: } 7.24 \\
(1.24-11.15)\end{array}$ & $\begin{array}{c}\text { Total: } 3684 \\
\text { (1031-7248) } \\
\text { Functional: } 9.15 \\
(5.33-13.35)\end{array}$ & $\begin{array}{r}0.273 \\
<0.001\end{array}$ & $\begin{array}{c}\text { Functional DKK-1 } \\
\text { correlates with } \\
\text { mSASSS }\end{array}$ & NA \\
\hline Taylan et al. ${ }^{[10]}$ & $55 / 33$ & 97 (17-771) & 115 (29-278) & 0.7 & $\begin{array}{l}\text { Correlates with BASMI, } \\
\text { sclerostin and SFRP-1 }\end{array}$ & $\begin{array}{l}\text { Higher in patients } \\
\text { receiving anti-TNF } \\
\text { than conventional } \\
\text { drugs }\end{array}$ \\
\hline Daoussis et al. ${ }^{[11]}$ & 45 vs. 50 & $2730 \pm 135.1$ & $2375 \pm 123.8$ & 0.040 & $\begin{array}{l}\text { No association with } \\
\text { disease duration, ESR, } \\
\text { CRP and mSASSS }\end{array}$ & Increased \\
\hline Hu et al. ${ }^{[12]}$ & 26 vs. 20 & $2254.6 \pm 725.4$ & $1879.2 \pm 467.1$ & 0.014 & $\begin{array}{l}\text { No association with } \\
\text { age, BASDAI, } \\
\text { BASFI, CRP, } \\
\text { ASDAS, lumbar } \\
\text { spine and SI joint } \\
\text { SPARCC scores } \\
\text { Negative correlated } \\
\text { with FDL }\end{array}$ & Decreased \\
\hline de Andrade et al..$^{[13]}$ & $52 \mathrm{SpA}$ vs.26 & $5798 \pm 5270$ & $3088 . \pm 2487$ & NA & NA & Increased \\
\hline Tuylu et al. ${ }^{[14]}$ & $94 / 68$ & $\begin{array}{c}1911 \pm 1344 \text { or } \\
1727 \pm 1083\end{array}$ & $672 \pm 592$ & $<0.0001$ & $\begin{array}{l}\text { Not correlated } \\
\text { with presense of } \\
\text { syndesmophtye }\end{array}$ & NA \\
\hline Klingberg et al. ${ }^{[15]}$ & $204 / 80$ & $2890(1140-7110)$ & $2660(850-6100)$ & 0.058 & $\begin{array}{l}\text { Correlates with } \\
\text { sclerostin and CRP }\end{array}$ & NA \\
\hline Korkosz et al. ${ }^{[16]}$ & $40 \mathrm{AS}$ & 196.8 (94.1-399) & NA & NA & Correlates with BMP-7 & Decreased \\
\hline Sakellariou et al. ${ }^{[17]}$ & $65 / 36$ & NA & NA & NA & $\begin{array}{l}\text { Not correlate with } \\
\text { periostin }\end{array}$ & NA \\
\hline Heiland 2012 & & NA & NA & NA & $\begin{array}{l}\text { Correlated to } \\
\text { sclerostin levels } \\
\text { but not to CRP }\end{array}$ & NA \\
\hline
\end{tabular}




\begin{tabular}{|c|c|c|c|c|}
\hline \multirow[t]{2}{*}{ Publication } & \multirow[t]{2}{*}{ Number (AS/HC) } & \multirow{2}{*}{$\frac{\text { OC level in AS }(\mathrm{ng} / \mathrm{mL})}{\text { Mean } \pm \text { SD }}$} & \multirow{2}{*}{$\frac{\text { OC level in } \mathrm{HC}(\mathrm{ng} / \mathrm{mL})}{\text { Mean } \pm \mathrm{SD}}$} & \multirow[t]{2}{*}{$p$} \\
\hline & & & & \\
\hline Borman et al. [26] (ng/mL) & $32 / 32$ & $32.5 \pm 14.9$ & $17.7 \pm 9.9$ & $<0.05$ \\
\hline Grisar et al..$^{[27]}(\mathrm{ng} / \mathrm{mL})$ & $30 / 41$ & $22.0 \pm 4.5$ & $17.8 \pm 5.5$ & $<0.05$ \\
\hline Toussirot et al. ${ }^{[28]}(\mathrm{ng} / \mathrm{mL})$ & $32 / 25$ & $7.2 \pm 3.2$ & $7.2 \pm 2.8$ & 1 \\
\hline Yilmaz and Ozaslan ${ }^{[29]}(\mathrm{ng} / \mathrm{mL})$ & $44 / 41$ & $9.7 \pm 1.2$ & $8.9 \pm 0.7$ & $>0.05$ \\
\hline Park et al. ${ }^{[30]}(\mathrm{ng} / \mathrm{mL})$ & $35 / 70$ & $11.7 \pm 3.3$ & $8.2 \pm 3.9$ & 0.06 \\
\hline Muntean et al. ${ }^{[31]}(\mathrm{ng} / \mathrm{mL})$ & $44 / 39$ & $24.4 \pm 9.9$ & $23 \pm 10.2$ & 0.55 \\
\hline Marhoffer et al. ${ }^{[32]}(\mathrm{ng} / \mathrm{mL})$ & $62 / 50$ & $3.5 \pm 1.2$ & $4.2 \pm 1.3$ & $>0.05$ \\
\hline Wendling et al. ${ }^{[33]}(\mathrm{ng} / \mathrm{mL})$ & 28/NA & $6.0 \pm 2.9$ & $7.1 \pm 3.1$ & $>0.05$ \\
\hline Speden et al. ${ }^{[34]}(\mathrm{ng} / \mathrm{mL})$ & $40 / 74$ & $7.5 \pm 2.9$ & $9.6 \pm 4.3$ & 0.02 \\
\hline \multicolumn{5}{|l|}{ Franck and $\operatorname{Keck}^{[35]}(\mathrm{ng} / \mathrm{mL})$} \\
\hline Men & $38 / 52$ & $1.7 \pm 1.1$ & $3.2 \pm 1.3$ & $<0.05$ \\
\hline $\begin{array}{l}\text { Women } \\
\text { [itra] }\end{array}$ & $50 / 20$ & $1.2 \pm 1.1$ & & \\
\hline 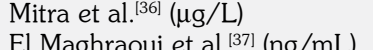 & $56 / 39$ & $9.0 \pm 2.7$ & $\begin{array}{l}11.1 \pm 2.3 \\
31.4+11.2\end{array}$ & $<0.001$ \\
\hline $\begin{array}{l}\text { El Maghraoui et al. }{ }^{[37]}(\mathrm{ng} / \mathrm{mL}) \\
\text { Sarikaya et al. }{ }^{[38]}(\mathrm{ng} / \mathrm{mL})\end{array}$ & $\begin{array}{l}29 / 30 \\
26 / 33\end{array}$ & $\begin{array}{r}22.1 \pm 8.3 \\
8.6 \pm 4.6\end{array}$ & $\begin{array}{l}31.4 \pm 11.2 \\
11.8 \pm 5.9\end{array}$ & $\begin{array}{l}0.003 \\
0.03\end{array}$ \\
\hline
\end{tabular}

in a previous study. ${ }^{15}$ Second, there might be a compensatory effect for DKK-1 in the pathway during AS bone formation, as suggested by a recent study. AS patients with no syndesmophyte formation show significantly higher functional DKK-1 levels, suggesting that blunted Wnt signaling suppresses new bone formation and consequently syndesmophyte growth and spinal ankylosis. ${ }^{18}$ Third, other negative regulator in the signaling pathway might also contribute. A low serum level of sclerostin in the setting of AS is linked to increased structural damage, emphasizing the role of sclerostin in the suppression of bone formation. ${ }^{24,25}$

Except for DKK-1, ALP and OC, the other markers including GSK-3 $\beta$ and $\beta$-catenin were to date the first to be evaluated in serum samples of AS patients. No significance was identified for these two markers between patients and controls, supporting future detection in cellular level to prove the dysfunction of this pathway.

As well known bone turnover markers, $\mathrm{OC}^{26-38}$ (supplemental data 2) and ALP $29,32,36,39-41$ (supplemental data 3) have been frequently assessed in AS in former studies; however, to our knowledge, they have not yet been evaluated in parallel with other markers in the Wnt signaling pathway. OC expression was similar between AS patients and controls. OC was the effector gene of the canonical Wnt pathway, but it might also be downstream factors of other signaling pathway. This complicated situation will interrupt the real expression that link to the canonical Wnt pathway. The result of ALP in our study was consistent with the former ones. ALP had a higher trend in AS, although it did not always reach significance. Increased serum ALP levels were associated with high disease activity, low bone mineral density, and higher structural damage scores in spondyloarthritis patients, ${ }^{42}$ which was also suggestive of activation of the signaling pathway.

In our study, when we investigated the correlation between components of the canonical Wnt pathway, high level of DKK-1 was not correlated with GSK-3 $\beta$ and $\beta$-catenin and also with disease activity indexes as well as pathologic

Supplemental data 3. Alkaline phosphatase levels in ankylosing spondylitis and controls

\begin{tabular}{|c|c|c|c|c|}
\hline \multirow[t]{2}{*}{ Publication } & Number (AS/HC) & ALP level in AS (U/L) & ALP level in $\mathrm{HC}(\mathrm{U} / \mathrm{L})$ & $p$ \\
\hline & $\mathrm{n}$ & Mean \pm SD & Mean \pm SD & \\
\hline Yilmaz and Ozaslann ${ }^{[29]}$ & $44 / 41$ & $76 \pm 17$ & $68.0 \pm 11$ & $>0.05$ \\
\hline Marhoffer et al. ${ }^{[32]}$ & $62 / 50$ & $149 \pm 50.3$ & $133 \pm 25.3$ & $>0.05$ \\
\hline Mitra et al. ${ }^{[36]}$ & $56 / 39$ & $73.1 \pm 19.5$ & $53.0 \pm 16.7$ & $<0.001$ \\
\hline Choi et al. ${ }^{[39]}$ & $30 / 23$ & $94.2 \pm 31.8$ & $47.1 \pm 11.4$ & $<0.001$ \\
\hline
\end{tabular}


indexes, suggesting that besides DKK-1, there must be other regulators contributing in the complicated mechanism of bone formation in AS.

Persistent systemic inflammation was associated with radiographic progression. ${ }^{43}$ The key treatment for AS was evaluated to be the blockade of bridging signal between inflammation and bone formation. Interestingly, we did not discover any correlation between bone turnover markers in canonical Wnt pathway and disease inflammation and radiographic indexes in AS patients in our study. Thus, further investigations are required to show whether Wnt signaling would trigger inflammation causing new bone formation in AS.

A limitation of this study was that the influence of treatment on bone turnover markers in Wnt signaling was not included. Some studies reported decreased DKK-1 level after TNF inhibitor treatment, which might theoretically lead to activation of Wnt pathway and eventually cause bone formation. According to the previous clinical trials, ${ }^{44-48}$ the structural progression in AS seems to be independent of TNF, despite the fact that TNF is responsible for the signs and symptoms due to inflammation in this disease. The paradoxical effects of TNF inhibitors on radiographic progression suggested that the inflammation and bone formation might be two independent processes in AS disease progress. The bone formation process was not retarded after anti-TNF treatment, implicating that other inflammation factors which may also trigger bone formation might exist synchronously. Explanation of this phenomenon needs further investigation.

In conclusion, the alteration of bone turnover markers in canonical Wnt pathway was observed in AS patients, while the results were not completely consistent with our hypothesis. The mechanism of canonical Wnt pathway in bone formation in AS might be explained by molecular dysfunction of these bone turnover markers and may not be reflected merely in serum level.

\section{Acknowledgments}

We thank Professor Yubin Deng from translational medicine research center of the First Affiliated Hospital of Sun Yat-sen University for assistance in study design and preparation of the manuscript.

\section{Declaration of conflicting interests}

The authors declared no conflicts of interest with respect to the authorship and/or publication of this article.

\section{Funding}

This research was supported by National Natural Sci ence Foundation of China (81301529), Natural Science Foundation of Guangdong Province (S2013040012296), Medical Scientific Research Foundation of Guangdong P rovince (A2015395), Science and Technology Planning Project of Guangdong Province (2014A020212617), Science and Technology Planning Project of Shenzhen (JCYJ20150331142757389) and Public Welfare Scientific Research Project of Futian District Shenzhen (FTWS201308).

\section{REFERENCES}

1. Corr M. Wnt signaling in ankylosing spondylitis. Clin Rheumatol 2014;33:759-62.

2. Haynes KR, Pettit AR, Duan R, Tseng HW, Glant TT, Brown MA, et al. Excessive bone formation in a mouse model of ankylosing spondylitis is associated with decreases in Wnt pathway inhibitors. Arthritis Res Ther 2012;14:253.

3. Uderhardt S, Diarra D, Katzenbeisser J, David JP, Zwerina J, Richards W, et al. Blockade of Dickkopf (DKK)-1 induces fusion of sacroiliac joints. Ann Rheum Dis 2010;69:592-7.

4. Zeng $\mathrm{X}$, Tamai $\mathrm{K}$, Doble $\mathrm{B}$, Li S, Huang $\mathrm{H}$, Habas R, et al. A dual-kinase mechanism for Wnt co-receptor phosphorylation and activation. Nature 2005;438:873-7.

5. Logan CY, Nusse R. The Wnt signaling pathway in development and disease. Annu Rev Cell Dev Biol 2004;20:781-810.

6. Daoussis D, Andonopoulos AP. The emerging role of Dickkopf-1 in bone biology: is it the main switch controlling bone and joint remodeling? Semin Arthritis Rheum 2011;41:170-7.

7. Kwon SR, Lim MJ, Suh CH, Park SG, Hong YS, Yoon BY, et al. Dickkopf-1 level is lower in patients with ankylosing spondylitis than in healthy people and is not influenced by anti-tumor necrosis factor therapy. Rheumatol Int 2012;32:2523-7.

8. Ustun N, Tok F, Kalyoncu U, Motor S, Yuksel R, Yagiz AE, et al. Sclerostin and Dkk-1 in patients with ankylosing spondylitis. Acta Reumatol Port 2014;39:146-51.

9. Yucong Z, Lu L, Shengfa L, Yongliang Y, Ruguo S, Yikai L. Serum functional dickkopf-1 levels are inversely correlated with radiographic severity of ankylosing spondylitis. Clin Lab 2014;60:1527-31.

10. Taylan A, Sari I, Akinci B, Bilge S, Kozaci D, Akar S, et al. Biomarkers and cytokines of bone turnover: extensive evaluation in a cohort of patients with ankylosing 
spondylitis. BMC Musculoskelet Disord 2012;13:191.

11. Daoussis D, Liossis SN, Solomou EE, Tsanaktsi A, Bounia K, Karampetsou M, et al. Evidence that Dkk-1 is dysfunctional in ankylosing spondylitis. Arthritis Rheum 2010;62:150-8.

12. Hu Z, Xu M, Li Q, Lin Z, Liao Z, Cao S, et al. Adalimumab significantly reduces inflammation and serum DKK-1 level but increases fatty deposition in lumbar spine in active ankylosing spondylitis. Int $\mathrm{J}$ Rheum Dis 2012;15:358-65.

13. de Andrade KR, de Castro GR, Vicente G, da Rosa JS, Nader M, Pereira IA, et al. Evaluation of circulating levels of inflammatory and bone formation markers in axial spondyloarthritis. Int Immunopharmacol 2014;21:481-6.

14. Tuylu T, Sari I, Solmaz D, Kozaci DL, Akar S, Gunay $\mathrm{N}$, et al. Fetuin-A is related to syndesmophytes in patients with ankylosing spondylitis: a case control study. Clinics (Sao Paulo) 2014;69:688-93.

15. Klingberg E, Nurkkala M, Carlsten H, Forsblad-d'Elia $\mathrm{H}$. Biomarkers of bone metabolism in ankylosing spondylitis in relation to osteoproliferation and osteoporosis. J Rheumatol 2014;41:1349-56.

16. Korkosz M, Gasowski J, Leszczynski P, Pawlak-Bus $\mathrm{K}$, Jeka S, Siedlar M, et al. Effect of tumour necrosis factor- $\alpha$ inhibitor on serum level of dickkopf- 1 protein and bone morphogenetic protein-7 in ankylosing spondylitis patients with high disease activity. Scand J Rheumatol 2014;43:43-8.

17. Sakellariou GT, Anastasilakis AD, Bisbinas I, Oikonomou D, Gerou S, Polyzos SA, et al. Circulating periostin levels in patients with AS: association with clinical and radiographic variables, inflammatory markers and molecules involved in bone formation. Rheumatology (Oxford) 2015;54:908-14.

18. Heiland GR, Appel H, Poddubnyy D, Zwerina J, Hueber A, Haibel $\mathrm{H}$, et al. High level of functional dickkopf-1 predicts protection from syndesmophyte formation in patients with ankylosing spondylitis. Ann Rheum Dis 2012;71:572-4.

19. van der Linden S, Valkenburg HA, Cats A. Evaluation of diagnostic criteria for ankylosing spondylitis. A proposal for modification of the New York criteria. Arthritis Rheum 1984;27:361-8.

20. van der Heijde D, Lie E, Kvien TK, Sieper J, Van den Bosch F, Listing J, et al. ASDAS, a highly discriminatory ASAS-endorsed disease activity score in patients with ankylosing spondylitis. Ann Rheum Dis 2009;68:1811-8.

21. Machado P, Landewé R, Lie E, Kvien TK, Braun $\mathrm{J}$, Baker D, et al. Ankylosing Spondylitis Disease Activity Score (ASDAS): defining cut-off values for disease activity states and improvement scores. Ann Rheum Dis 2011;70:47-53.

22. Creemers MC, Franssen MJ, van't Hof MA, Gribnau FW, van de Putte LB, van Riel PL. Assessment of outcome in ankylosing spondylitis: an extended radiographic scoring system. Ann Rheum Dis
2005;64:127-9.

23. Diarra D, Stolina M, Polzer K, Zwerina J, Ominsky MS, Dwyer D, et al. Dickkopf-1 is a master regulator of joint remodeling. Nat Med 2007;13:156-63.

24. Clarke BL, Drake MT. Clinical utility of serum sclerostin measurements. Bonekey Rep 2013;2:361.

25. Appel H, Ruiz-Heiland G, Listing J, Zwerina J, Herrmann M, Mueller R, et al. Altered skeletal expression of sclerostin and its link to radiographic progression in ankylosing spondylitis. Arthritis Rheum 2009;60:3257-62.

26. Borman P, Bodur H, Bingöl N, Bingöl S, Bostan EE. Bone mineral density and bone turnover markers in a group of male ankylosing spondylitis patients: relationship to disease activity. $\mathrm{J}$ Clin Rheumatol 2001;7:315-21.

27. Grisar J, Bernecker PM, Aringer M, Redlich K, Sedlak $\mathrm{M}$, Wolozcszuk W, et al. Ankylosing spondylitis, psoriatic arthritis, and reactive arthritis show increased bone resorption, but differ with regard to bone formation. J Rheumatol 2002;29:1430-6.

28. Toussirot E, Ricard-Blum S, Dumoulin G, Cedoz JP, Wendling $D$. Relationship between urinary pyridinium cross-links, disease activity and disease subsets of ankylosing spondylitis. Rheumatology (Oxford) 1999;38:21-7.

29. Yilmaz N, Ozaslan J. Biochemical bone turnover markers in patients with ankylosing spondylitis. Clin Rheumatol 2000;19:92-8.

30. Park MC, Chung SJ, Park YB, Lee SK. Bone and cartilage turnover markers, bone mineral density, and radiographic damage in men with ankylosing spondylitis. Yonsei Med J 2008;49:288-94.

31. Muntean L, Rojas-Vargas M, Font P, Simon SP, Rednic S, Schiotis R, et al. Relative value of the lumbar spine and hip bone mineral density and bone turnover markers in men with ankylosing spondylitis. Clin Rheumatol 2011;30:691-5.

32. Marhoffer W, Stracke H, Masoud I, Scheja M, Graef $\mathrm{V}$, Bolten $\mathrm{W}$, et al. Evidence of impaired cartilage/ bone turnover in patients with active ankylosing spondylitis. Ann Rheum Dis 1995;54:556-9.

33. Wendling D, Cedoz JP, Racadot E, Dumoulin G. Serum IL-17, BMP-7, and bone turnover markers in patients with ankylosing spondylitis. Joint Bone Spine 2007;74:304-5.

34. Speden DJ, Calin AI, Ring FJ, Bhalla AK. Bone mineral density, calcaneal ultrasound, and bone turnover markers in women with ankylosing spondylitis. J Rheumatol 2002;29:516-21.

35. Franck H, Keck E. Serum osteocalcin and vitamin D metabolites in patients with ankylosing spondylitis. Ann Rheum Dis 1993;52:343-6.

36. Mitra D, Elvins DM, Collins AJ. Biochemical markers of bone metabolism in mild ankylosing spondylitis and their relationship with bone mineral density and vertebral fractures. J Rheumatol 1999;26:2201-4. 
37. El Maghraoui A, Tellal S, Chaouir S, Lebbar K, Bezza A, Nouijai A, et al. Bone turnover markers, anterior pituitary and gonadal hormones, and bone mass evaluation using quantitative computed tomography in ankylosing spondylitis. Clin Rheumatol 2005;24:346-51.

38. Sarikaya S, Basaran A, Tekin Y, Ozdolap S, Ortancil O. Is osteoporosis generalized or localized to central skeleton in ankylosing spondylitis? J Clin Rheumatol 2007;13:20-4.

39. Choi ST, Kim JH, Kang EJ, Lee SW, Park MC, Park $\mathrm{YB}$, et al. Osteopontin might be involved in bone remodelling rather than in inflammation in ankylosing spondylitis. Rheumatology (Oxford) 2008;47:1775-9.

40. Sheehan NJ, Slavin BM, Kind PR, Mathews JA. Increased serum alkaline phosphatase activity in ankylosing spondylitis. Ann Rheum Dis 1983;42:563-5.

41. Smith DH, Spencer DG, Allam BF, Farish E, Borland WW. Serum alkaline phosphatase in ankylosing spondylitis. J Clin Pathol 1979;32:853-4.

42. Kang KY, Hong YS, Park SH, Ju JH. Increased serum alkaline phosphatase levels correlate with high disease activity and low bone mineral density in patients with axial spondyloarthritis. Semin Arthritis Rheum 2015;45:202-7.

43. Pedersen SJ, Sørensen IJ, Lambert RG, Hermann KG, Garnero P, Johansen JS, et al. Radiographic progression is associated with resolution of systemic inflammation in patients with axial spondylarthritis treated with tumor necrosis factor- $\alpha$ inhibitors: a study of radiographic progression, inflammation on magnetic resonance imaging, and circulating biomarkers of inflammation, angiogenesis, and cartilage and bone turnover. Arthritis Rheum 2011;63:3789-800.

44. van der Heijde D, Landewé R, Einstein S, Ory P, Vosse $\mathrm{D}, \mathrm{Ni} \mathrm{L}$, et al. Radiographic progression of ankylosing spondylitis after up to two years of treatment with etanercept. Arthritis Rheum 2008;58:1324-31.

45. Dijkmans B, Emery P, Hakala M, Leirisalo-Repo M, Mola EM, Paolozzi L, et al. Etanercept in the longterm treatment of patients with ankylosing spondylitis. J Rheumatol 2009;36:1256-64.

46. van der Heijde D, Landewé R, Baraliakos X, Houben $H$, van Tubergen A, Williamson $P$, et al. Radiographic findings following two years of infliximab therapy in patients with ankylosing spondylitis. Arthritis Rheum 2008;58:3063-70.

47. van der Heijde, Salonen D, Weissman BN, Landewé R, Maksymowych WP, Kupper H, et al. Assessment of radiographic progression in the spines of patients with ankylosing spondylitis treated with adalimumab for up to 2 years. Arthritis Res Ther 2009;11:127.

48. Kang KY, Ju JH, Park SH, Kim HY. The paradoxical effects of TNF inhibitors on bone mineral density and radiographic progression in patients with ankylosing spondylitis. Rheumatology (Oxford) 2013;52:718-26. 